\title{
Health workforce malldistribution: Lesson from central Lampung Regency in Indonesia
}

\author{
Simon Sumanjoyo Hutagalung ${ }^{1}$, Dedy Hermawan ${ }^{2}$, Devi Aulia ${ }^{3}$ \\ ${ }^{1,2}$ Department of Public Administration, University of Lampung, Indonesia \\ ${ }^{3}$ Health Office of Bandar Lampung Municipal, Indonesia
}

\begin{tabular}{l} 
Article Info \\
\hline Article history: \\
Received Feb 25, 2020 \\
Revised Apr 30, 2020 \\
Accepted Jun 28, 2020 \\
\hline Keywords: \\
Health workforce \\
Human resource management \\
Human resource policy \\
Public health \\
Workforce distribution
\end{tabular}

\begin{abstract}
The purpose of this study is to explain: (1) Distribution of health workers in basic health services in Central Lampung, and (2). Factors that influence the process of procurement and distribution of health workers in primary health care in Central Lampung. Research conducted with this descriptive qualitative method involved health stakeholders in 34 health centers and 17 hospitals in the region. The results of this study include: (a). Analysis of the Distribution of Health Workers by Region, it is known that the pattern of distribution is not balanced and there are some districts that do not have several types of health workers. (b). Analysis of power distribution based on health workplaces is known that the majority of health workers are in health centers, even midwives and nurses are mostly in health centers and some types of health workers are not yet available in health centers. Also known factors that influence the process of procurement and distribution of health workers in primary health care include structural and environmental factors.
\end{abstract}

This is an open access article under the CC BY-SA license.

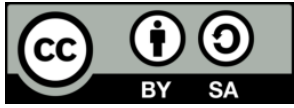

\section{Corresponding Author:}

Simon Sumanjoyo Hutagalung,

Department of Public Administration,

University of Lampung,

Jln. Sumantri Brojonegoro No 1 Gedung Meneng, Bandar Lampung, Indonesia.

Email: simon.sumanjoyo@ fisip.unila.ac.id

\section{INTRODUCTION}

Implementation of the decentralization of health at the start of its implementation having some problems like not all of the population covered by a participant, the distribution of health services are not equitable, quality health services varies, the referral system and the payment is not optimal [1]. Inequality availability of health facilities, human resources, health and geographical conditions are very varied, poses a potential widening health inequities between groups of people [2].

Data from Indonesian Medical Council showing the number of general practitioners and specialists registered by September 2017 respectively 120,509 and 33,963. Magnitude was actually already exceeded the target achievement in 2019, ie 45 general practitioners and 11 specialists for 100 thousand inhabitants. Unfortunately, the big cities are still the target of the doctors to serve [3], As a result, more than half the doctors accumulate in urban areas in western Indonesia. The impact of the distribution of health personnel are unequal impact on society difficulty accessing health services. Head of Development and Empowerment of Health Human Resources on Health Ministry, Usman Sumantri said 14.7\% health centers had doctors and $16.76 \%$ do not have health professionals such as midwives and nurses.

Based on the mapping of the Ministry of Health, areas which is lacking of doctors and health care workers generally happen in eastern Indonesia [4]. However, the worst condition occurs in underdeveloped regions, frontier, outer islands, and ironically also occur in areas of health problems. Very striking inequality of distribution is of course very sad [5], the ratio of healthcare providers in Indonesia is lower than 
the average of South-East Asian and other lower middle income countries [6], in addition it is coupled with problems in the behavior of health workers who are still lame [7]. Supposedly, all Indonesian citizens wherever they may be and whatever their isolated area entitled to the same health services.

In Indonesia Health System, a region is an organized unit of local government, and a local health subsystems more or less a self-contained segment of the national health system. This subsystem consists of a well-defined population living within the administrative and geographical boundaries are clear, both in cities and villages [8]. These subsystems include in it all the persons, institutions, and sectors whose activities aim to improve health. To achieve a healthy area required excellent health services even though the wave of decentralization in Indonesia resulted in institutional changes that were detrimental to innovation [9]. Whereas discretion for local-level decision makers increased compared to the situation under the former centralized system, requirements for accountability did not [10]. The dynamics of decentralization that are becoming more mature are a prerequisite for a well-functioning primary health care system which is fundamental for a nation's overall health performance [11].

The number of health workers indirectly affect the degree of development of a nation [12]. Logically, the more health workers are available in a region, it will automatically affect the access, cost and quality of health services [13]. A large quantity of health personnel, there will be plenty of choice for consumers who need it. User access services will also become much closer in distance and time. Likewise utilities health services will increase with the availability of more options for public needs. In terms of quantity this problem will be related to the recruitment process carried out by the government, inequality comes from the number and composition of health workers that are not well planned. Planning of the health workforce is done at the central level and the local level. Since decentralization, the district/municipality is allowed to assess its own human resource needs. At the local level, human resource planning is done by the institutions using various methods, for instance, the list of positions and/or workload indicator of staffing needs, and is also done by the local health offices to meet local demands, including for disaster preparedness.

Central Lampung as one of the decentralized areas is the area with the widest area and the largest population in Lampung Province, recorded in 2014 a total of 1227185 inhabitants [14]. Demographic conditions that are in the middle of the mainland and traversed by cross-regional lanes make this regency have characteristics of population mobility in groups based on the identity of certain groups. Diseases that are often found in Central Lampung include dengue hemorrhagic fever (DHF), withered paralysis, and leprosy. Another health problem is the high stunting rate in Lampung. In addition, it was also noted that $14 \%$ of the people of Lamteng suffer from psychiatric disorders [15]. Geographical and demographic conditions and the health situation that occurred in this area were detected due to poor resource planning, including in terms of health human resources [16].

Therefore, the presence of health workers sufficient quantity and good quality become urgent. Including on the territory of Central Lampung regency who need to know the process of procurement and distribution of health personnel, so that will be able to produce a redistribution policy reference for basic services of health workers in Central Lampung. The formulation of the problem in this research are: (a). How is the distribution of existing health workers in primary health care in Central Lampung?, (b). What are the factors that affect the process of procurement and distribution of health personnel in primary health care in Central Lampung?.

\section{RESEARCH METHOD}

This research was conducted in Central Lampung regency involving health stakeholders at 34 health centers and 17 hospital in region. This research is a descriptive qualitative research, where researchers attempt to decipher and analyze information obtained through the facts. As for the focus of this research, among others; (1) Analysis of the existing distribution of health personnel in primary health care in Central Lampung is done by identifying the quantity and quality of existing health workers in basic services are distributed in the region of Central Lampung, (2) Analysis of the factors that affect the process of procurement and distribution of health personnel in primary health care in Central Lampung done by identifying and outlining aspects of policy, institutional and other factors that have an effect on the health condition of power distribution on the basic service today. Data collected through interviews, focus group discussions and observation. The data obtained in this study will be analyzed and described based on the findings of the facts of research in the field. Meanwhile, data analysis is conducted qualitatively by a model of interactive analysis. Institutional and other factors that have an effect on the health condition of power distribution on the basic service today. Data collected through interviews, focus group discussions and observation. The data obtained in this study will be analyzed and described based on the findings of the facts of research in the field. Meanwhile, data analysis is conducted qualitatively by a model 
of interactive analysis. Institutional and other factors that have an effect on the health condition of power distribution on the basic service today. Data collected through interviews, focus group discussions and observation. The data obtained in this study will be analyzed and described based on the findings of the facts of research in the field. Meanwhile, data analysis is conducted qualitatively by a model of interactive analysis.

\section{RESULTS AND DISCUSSION}

\subsection{Existing condition of primarly level health workforce}

\subsubsection{Analysis of health resources distribution by region}

Analysis of the distribution of health personnel by area was conducted to determine the pattern of the health personnel, which is distributed in various districts in Central Lampung. From these patterns will be known locations with less quantity of resources and the already excessive. At a later stage may be material to the decision on the redistribution of health workers for the sake of equal distribution of health services in the entire territory of Central Lampung. Table 1 shows overall health workers distribution based on district in Central Lampung.

Table 1. Distribution of health workers by district in Central Lampung

\begin{tabular}{|c|c|c|c|c|c|}
\hline \multirow{2}{*}{ Districts } & \multicolumn{5}{|c|}{ Health workers/Health Personnel } \\
\hline & Medical & Nurses & Midwifery & Pharmaceutical & Others \\
\hline Padang Ratu & 16 & 14 & 18 & 0 & 6 \\
\hline Selagai Lingga & 1 & 6 & 16 & 1 & 1 \\
\hline Pubian & 3 & 11 & 12 & 0 & 5 \\
\hline Anak Tuha & 1 & 17 & 13 & 0 & 4 \\
\hline Anak Ratu Aji & 1 & 7 & 8 & 1 & 9 \\
\hline Kalirejo & 4 & 30 & 22 & 0 & 4 \\
\hline Sendang Agung & 3 & 10 & 24 & 1 & 5 \\
\hline Bangun Rejo & 3 & 18 & 25 & 0 & 2 \\
\hline Gunung Sugih & 5 & 20 & 29 & 3 & 37 \\
\hline Bekri & 3 & 5 & 13 & 1 & 6 \\
\hline Bumi Ratu Nuban & 1 & 10 & 10 & 0 & 1 \\
\hline Trimurjo & 4 & 32 & 49 & 0 & 9 \\
\hline Punggur & 3 & 21 & 37 & 1 & 32 \\
\hline Kota Gajah & 2 & 15 & 27 & 1 & 9 \\
\hline Raman Utara & 2 & 25 & 35 & 1 & 5 \\
\hline Terbanggi Besar & 8 & 24 & 38 & 5 & 17 \\
\hline Seputih Agung & 2 & 10 & 17 & 1 & 4 \\
\hline Way Pengubuan & 1 & 8 & 11 & 0 & 5 \\
\hline Terusan Nunyai & 1 & 14 & 13 & 1 & 3 \\
\hline Seputih Mataram & 3 & 15 & 34 & 0 & 3 \\
\hline Bandar Mataram & 3 & 8 & 22 & 0 & 8 \\
\hline Seputih Banyak & 1 & 12 & 22 & 0 & 4 \\
\hline Way Seputih & 1 & 5 & 7 & 0 & 0 \\
\hline Rumbia & 3 & 5 & 19 & 0 & 7 \\
\hline Bumi Nabung & 1 & 7 & 9 & 0 & 2 \\
\hline Putra Rumbia & 0 & 6 & 9 & 0 & 4 \\
\hline Seputih Surabaya & 1 & 10 & 25 & 0 & 2 \\
\hline Bandar Surabaya & 3 & 9 & 7 & 0 & 2 \\
\hline Central Lampung & 80 & 374 & 571 & 17 & 196 \\
\hline
\end{tabular}

From the table it can be observed that medical personnel are most numerous in the district of Padang Ratu with the number 16, while nurses are most numerous in the District Trimurjo with the number 32. In addition midwives are most numerous in the District Terbanggi Besar with the number 38 and the pharmacy staff are most numerous in the District of Terbanggi Besar also by the number of 5 people. In the latter type are Medicals Others known to most in the District of Gunung Sugih with the number 37.

The distribution can be observed from the distribution pattern that has not been balanced, where there are health workers who have large quantities, such as Sub Terbanggi Great, Trimurjo and Padang Ratu. While there are some districts that do not have some type of health personnel, such as Sub Rumbia which do not have medical personnel. Medical personnel are experts of medicine with its main function is to provide medical care to patients with the best possible quality using the procedures and techniques based on medical science and ethics and accountability [17]. Based on the Indonesian Government Regulation No. 32 Year 1996 about Health Workers, which referred to the medical personnel include doctors and dentists. Medical personnel are those whose professions in the medical field, namely physicians, physician or dentist. The distribution pattern of medical personnel can be seen in Figure 1 . 


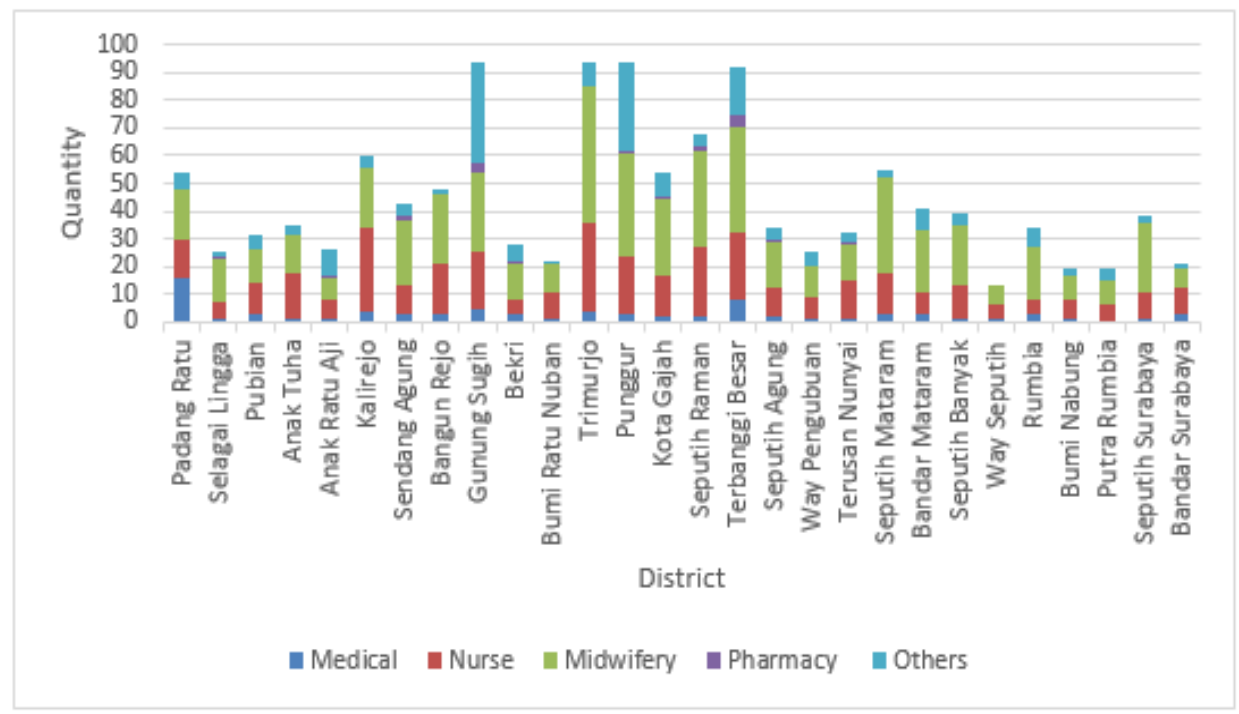

Source: Central Lampung Regency Health Profile, 2018 and Central Lampung in Figures, 2018

Figure 1. District based health workforce distribution in Central Lampung

From the Figure 1, it can be observed that there are some districts that already have the capacity of health workers is adequate and there are seven sub-district which has a capacity of health workers minimal, the District Anak Ratu Aji, Bumi Ratu Nuban, Way Pengubuan, Way Seputih, Bumi Nabung, Putra Rumbia and Bandar Surabaya. Based on data from the Department of Health in Central Lampung, it is known if the ratio of general practitioners to 100,000 new residents reached 10.62, still far from the target number 15. Meanwhile, the ratio of general practitioners to the health center facilities of 1.69, which means that every health center have an average of 1 doctors and nothing has 2 doctors. While the ratio of specialists to 100,000 people stood at 7.37 per 100,000 population, which means that it meets the target of 5 per 100,000 population. In addition, the ratio of dentists to 100,000 population by 1.82, the figure is still far from the target of 8 per 100,000 population. In terms of the ratio of dentists to Puskesmas of 0.59 which means that not all health center dentists (1 Dentist to one Puskesmas).

Figure 2 shows that the District Padang Ratu has a dominant quantity of medical personnel (16 persons), followed by the District Terbanggi Besar in the second (8) and the District of Gunung Sugih in third ( 5 people). This is apparent in contrast to the District Rumbia who do not have any medical personnel. This indicates that the deployment of medical personnel have not been evenly on the entire region of Central Lampung regency.

The next health workers are nurses is person who has graduated nurse education and have the ability and authority to perform nursing actions based on science that is owned and provide holistic health services and professionals to healthy or diseased individuals [18]. Based on data from the Health Service Central Lampung regency is unknown if the ratio of nurses to 100,000 population amounted to 78.72 per 100,000 population. This proportion is still far below the target of 115 per 100,000 population. Figure 3 informs that there is a district which has nurses up to 32 people (Trimurjo sub-district) and 30 (subdistrict Kalirejo). While there are some districts that have minimal nursing personnel, ie 5 people in the District Bekri, Way Seputih and Rumbia. Observing the distribution, it can be understood if the equitable distribution of nurses have not been distributed properly.

The next health worker is Midwifery, they has a special role in maternal and child health services. The midwife is a woman who graduated from midwife recognized by the government and professional organizations in the territory of the Republic of Indonesia and has the competence and qualifications to be registered, certified or legally licensed to practice. Based on data from the Department of Health Central Lampung regency is known that the ratio of midwives to 100,000 people stood at 59.53 per 100,000 people. The portion is still far from the target of Central Lampung, which is 95 per 100,000 population.

Figure 4 as shows that their several Districts have Midwifery in large numbers, including the District Trimurjo (49) and the District Terbanggi Besar (38). Meanwhile, there are also some Districts have midwives in a minimal amount, including the District Way Seputih and the District Seputih Surabaya (7) and the District Anak Ratu Aji (8). From the distribution of power can be understood if the spread of midwifery in the region of Central Lampung is not distributed evenly. 
The next health worker is pharmacy staff that have a role in the management of medicines is a pharmaceutical power, this worker is required at the first health facility in order to maintain the quality and standards of adequate drugs. They roles is a pharmacy include pharmacists, assistant pharmacists, as well as associate expert. In setting up a pharmacy should have a pharmacist undertaking, as well as pharmacist assistant who helped him. A pharmacist must be responsible for its management pharmacy, medicine and whatever entry is allowed and is not issued; as well as other services to be provided in a pharmacy. It's all clearly set out in the Health Act. As well, a pharmacist's assistant also assists the pharmacist in accordance with the implementing authority as a pharmacist's assistant. Figure 5 shows the distribution of pharmaceutical workers by district in Central Lampung from the Figure 5 above it can be observed there have been several districts that have pharmacy staff more than one person, including the District Terbanggi Besar (5) and the District of Gunung Sugih (3). While in almost all sub-district have only one pharmacy staff even 17 districts in Central Lampung have not had this type of health personnel.

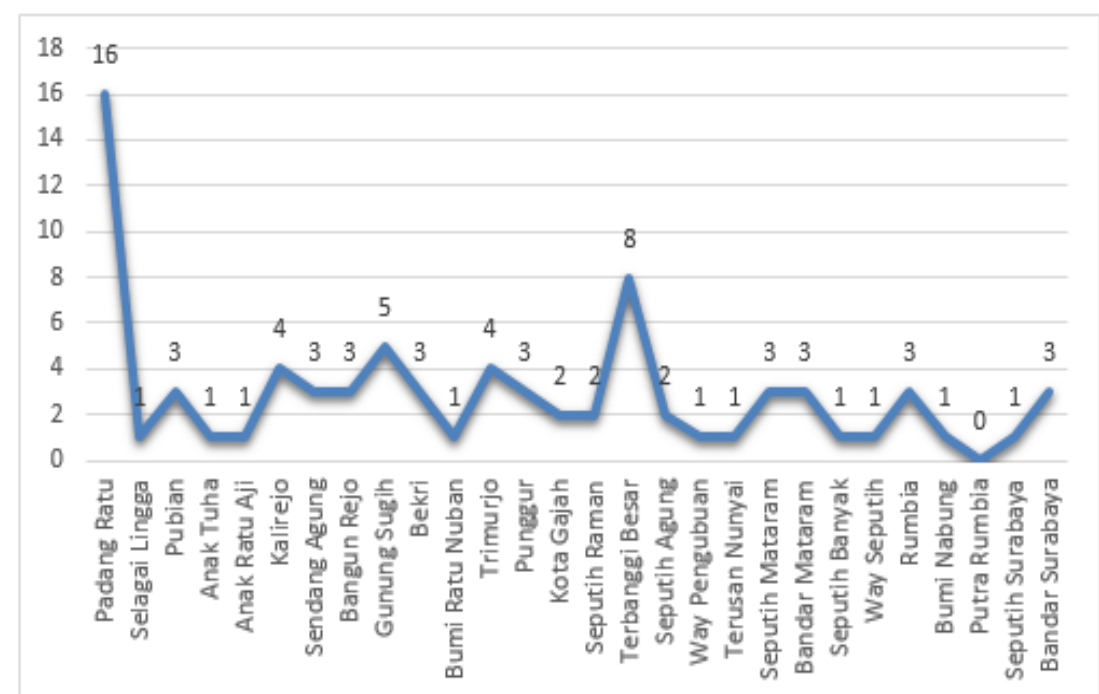

Source: Central Lampung District Health Profile, 2018 and Central Lampung in Figures, 2018.

Figure 2. Medical workforce distribution in district in Central Lampung

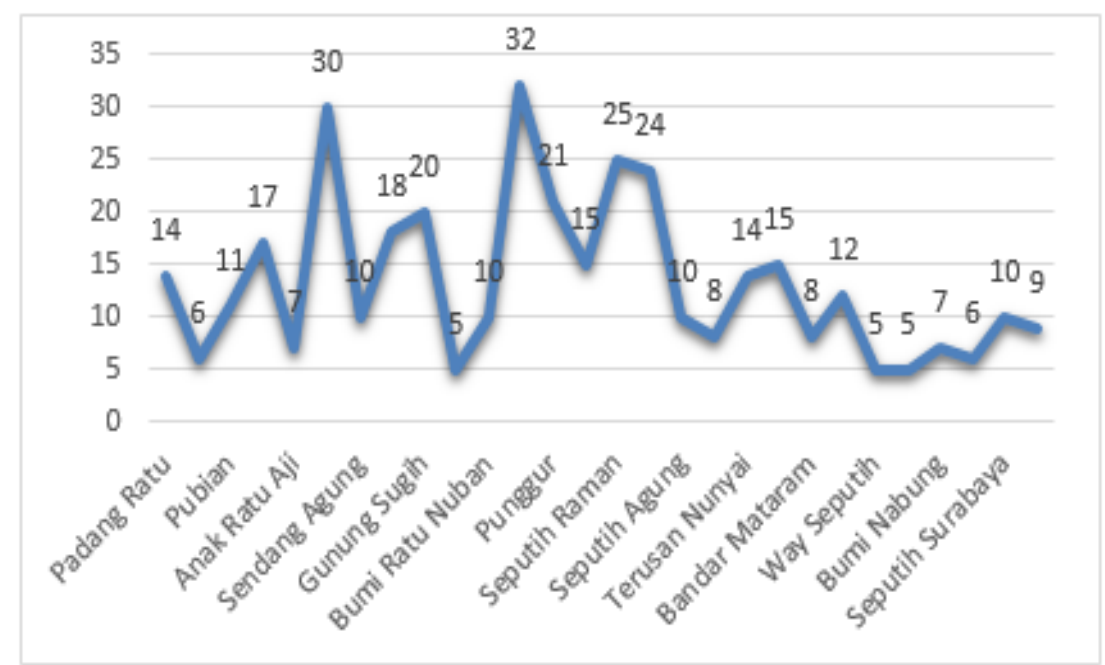

Source: Central Lampung Health Profile, 2018 and Central Lampung in Figures, 2018

Figure 3. Nurses distribution by district in Lampung Tengah 


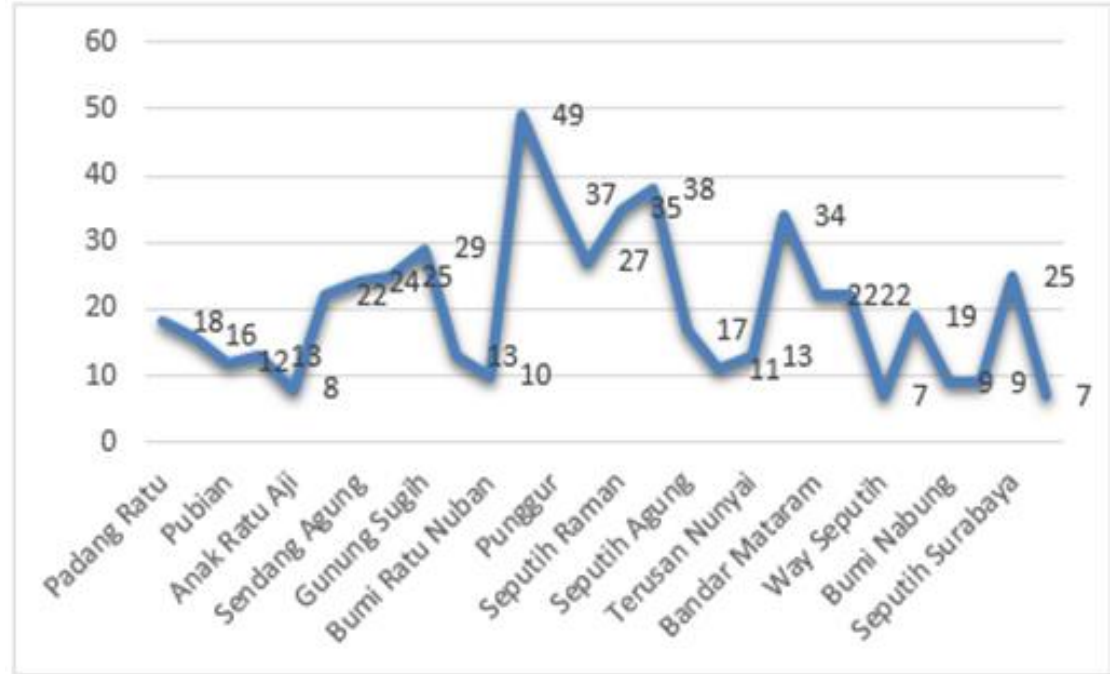

Source: Central Lampung Health Profile, 2018 and Central Lampung in Figures, 2018

Figure 4. Midwifery distribution by district in Central Lampung regency

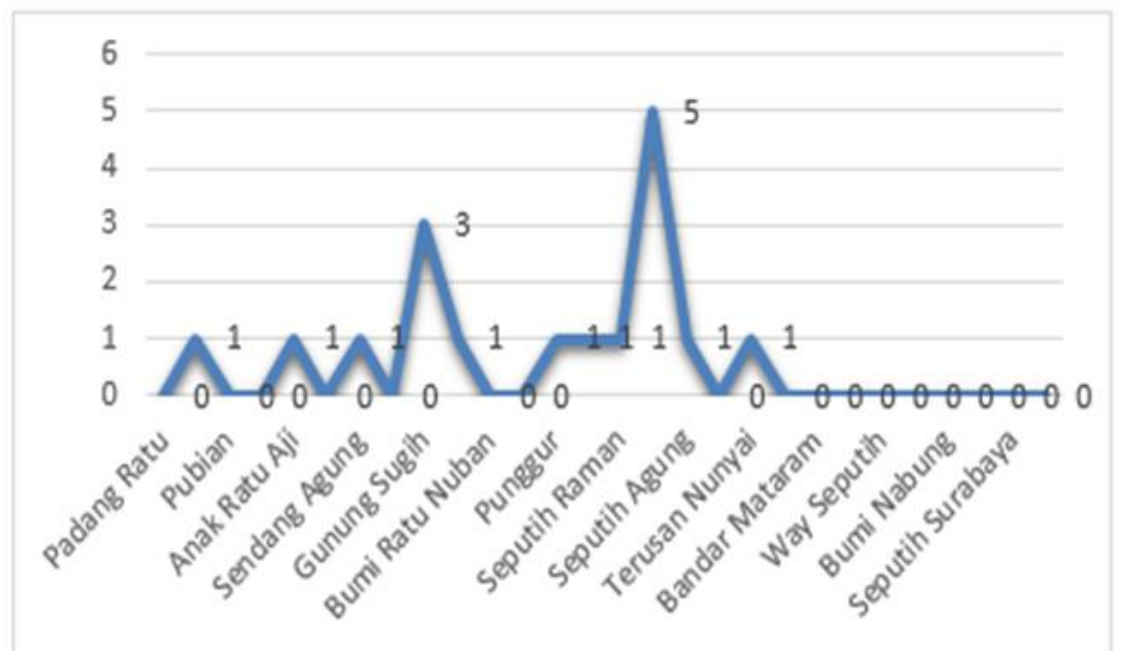

Source: Central Lampung Health Profile, 2018 and Central Lampung in Figures, 2018

Figure 5. Distribution of pharmaceutical workforce in Central Lampung

\subsubsection{Analysis of health personnel distribution based on workplace health}

In this section we analyzed the distribution of health personnel in the region of Central Lampung Based on a work placement, it aims to understand the distribution patterns are more likely to occur if standards compliance or first-level health facilities are more likely to means thereon. There are at least three categories of health personnel placement locations, ie, at the Department of Health, health centers and hospitals. Based on Figure 6 as shown in, it can be observed if the majority of health workers are on the placement location clinic, even the highest number of midwives and nurses are as great majority are in the health center. In some types of health workers in health centers seems not available. It is also a record of the Department of Health Central Lampung regency.

When further analyzed in detail it will show a distribution pattern that occurs in some types of health personnel, including medical personnel. Figure 7 informs that the type of medical general practitioner more absorbed in Puskesmas (66) even when compared to the quantity of general practitioners in hospitals are also large (52 people) and maternity homes (12 people). While on the type of medical personnel dentist more scattered at PHC facilities (14) as compared with working in hospital facilities (9). On this kind of specialist medical personnel are visible dominant in hospital facilities (85) and there are no specialists in PHC facilities. 
In other types of health workers, the paramedics and nurses can be analyzed non paramedical distribution pattern which is dominant in the health center. The condition can be understood given the quantity of health centers located in the region of Central Lampung procurement opportunities paramedics and paramedics non nurse becomes more. It can be observed paramedics were dominant in the health center, including power Nurses (363) and midwives (618 people). When compared with the number of medical personnel who are in hospital it can be said of their distribution based on the location of work is good enough. However, that should be noted is the unavailability of a number of non nurse paramedical personnel, for example, medical records personnel, physiotherapy and dental techniques.

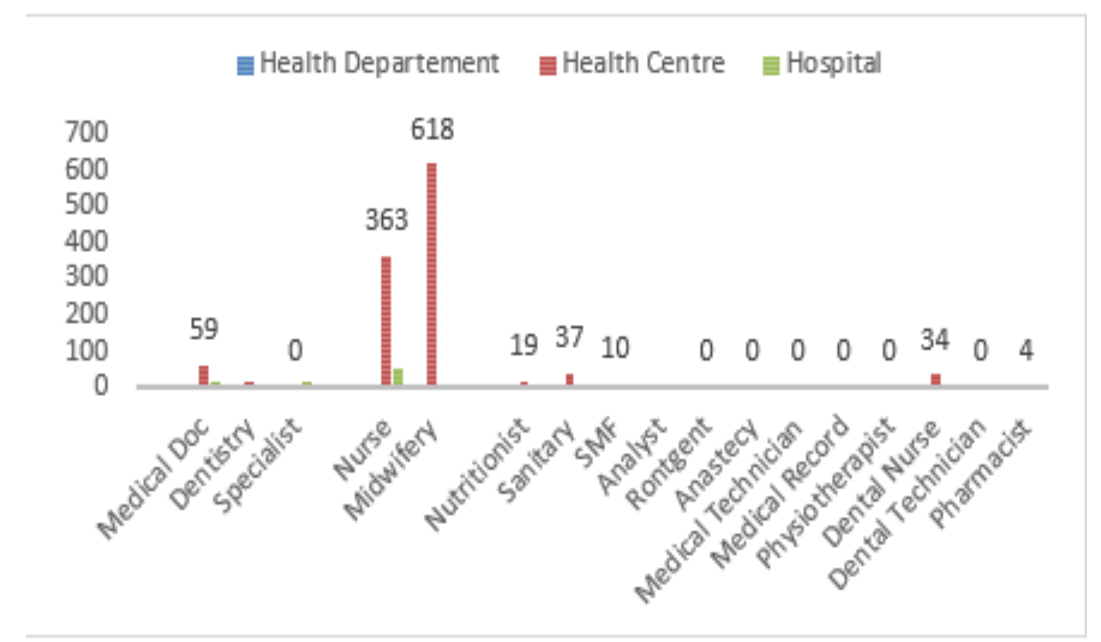

Source: Central Lampung District Health Profile, 2018 and Central Lampung in Figures, 2018

Figure 6. Medicals distribution by job location category

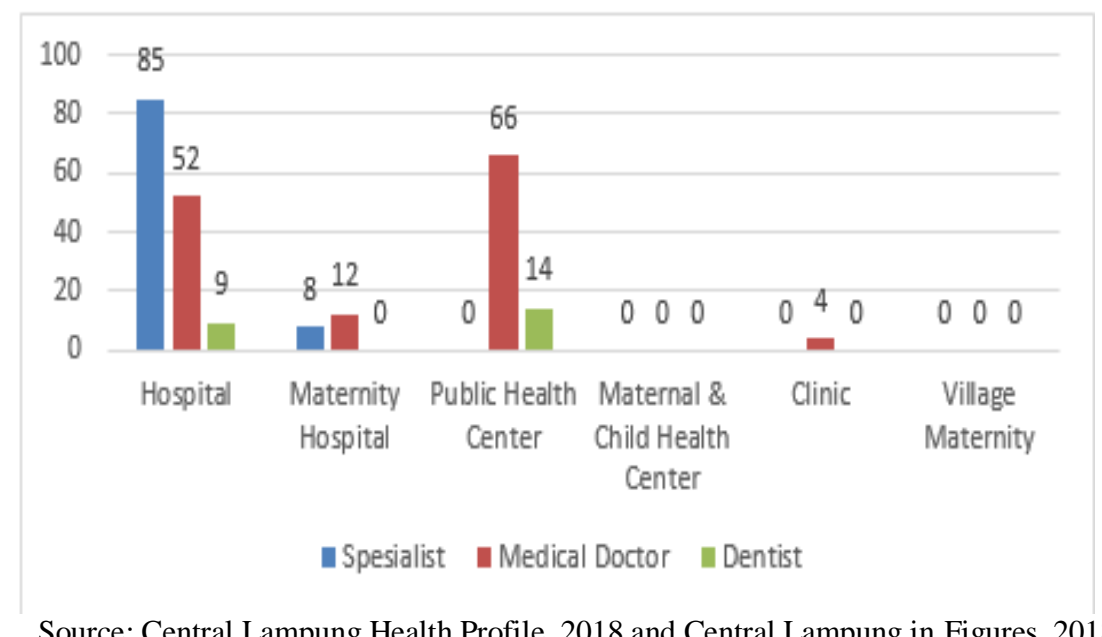

Figure 7. Distribution of medical doctors based on the workplace

\subsection{Factors affected procurement process $\&$ distribution of health personnel in primary health care}

There are several factors that affected procurement and distribution of first-level health workers in Central Lampung, including:

\subsubsection{Position analysis of the health workers have not been done at the health center level}

Job analysis is an activity to gather information related to positions in a systematic and organized, among others, the following dimensions and indicators of employment; education and competence of personnel needed; technology/equipment needed; operating procedures carry out the work; working result; 
executive power compensation; techniques to assess the performance [19]. Job analysis (job analysis) is performed to obtain a description of the work and the basis for further process of human resource management [20]. Based on interviews with Ms. Damayanti, as Secretary of Health Office of Central Lampung regency job analysis activities performed only at the level of service has not been performed by each health center. The results of job analysis is to be used by the department for filing when there is an opening formation civil servant selection in Central Lampung regency. Not to do this job analysis is suspected as a cause has not been able to unavailability of health workers at the health center level, as well as the causes of the problems that tend to be uneven distribution in the region of Central Lampung. Analysis of this position is recognized as important in the administration of health center functions and duties which require adequate human resources in order to health services that do achieve optimum results realized in the future so that the goal of public health degree increase in the coverage area of Health Centre [21].

Fixed health care workers, including doctors, nurses and midwives in health centers are Civil Servants and Government Employees Labor Agreement, so that compliance in the work will have its own characteristics according to the loyalty of each individual officer in the works [22]. In addition, the supervision, monitoring and penalties also determine the compliance officer. Compliance officers in the work will affect the performance of personnel, both individually and team [23], In actual fact the interaction between health care workers at the health center with communities and users of health services in health centers mostly done by paramedics mainly doctors, nurses and midwives [24]. Most of the time these interactions when doing health services in health centers and the rest is done directly in the community such as the IHC, Roving health center and other activities [25]. Therefore, the implementation of job analysis as the database to propose civil servant formation recruitment has become a necessity.

\subsubsection{Health personnel information system has not been implemented, so that the data has not been collected health workers and exploited better.}

Health Information System is an information management at all levels of government systematically in the context of the provision of services to the community. Health Information System that effectively provide information support for keputusandi making processes at all levels of health administration, particularly in the health centers into Primary Health Care Unit. Health Act mandates that health efforts to organize an effective and efficient health information held by the information system and across sectors. Every operator of health care facilities, including those organized health care facilities must provide the infrastructure for health information systems, including institutional, tools, technology, and human resources (Article 45 of Regulation No. 46 of 2014). This shows how important the role of health information systems within a health system. But for the Health Information System in Indonesia, is still inadequate so it can not provide accurate data and timely [26]. The result is that stakeholders and policy makers the heads of health centers, Hospitals, Health Service and officials in the Ministry of Health, it becomes difficult to make decisions for program planning in order to support health development. These conditions are also revealed in an interview with the Department of Health Central Lampung represented by Ms. Damayanti as informants.

Presented by Ms. Damayanti as Secretary of Health Office of Central Lampung that the use of information systems is not maximized operational, it is not only caused by as yet insufficient experts competent operator, geographic regions that have a signal strength of the Internet is different and also the condition of electrical infrastructure that is still often faced harassment, In fact, the Department also understand that their health information systems to better facilitate decision-making, including in terms of candidate recruitment planning and health personnel can determine the distribution of health personnel in the region of Central Lampung. In addition, conventional systems are still a majority applied by management bodies pelayananan health, especially in the health centers, making the limited access to information and doubted the quality of existing data. This is evidenced by the frequent differences between the Department of Health with the data related to the health center. So it can be easily concluded the process of decision-making and public health policy by the Department of Health relating becoming ineffective due to the latest information received and coupled with data quality issues [27].

3.2.3. Coordination between the relevant institutions for recruitment is not optimal, often proposals from the department then changed during the process of formation at the level of civil service agency or the central government

In the implementation of each activity personnel must pass through the stages in achieving the objectives of the organization's activities. Regional Civil Service Office as regional agency responsible for staffing activities in the area of managing the process of recruitment of Civil Servants region [28]. The stages in the process of recruitment by local governments, namely: (a). Requirements Planning Officer, Department of Health Central Lampung in terms of planning needs of these employees do collate regional civil 
servants formation by considering the proposals of each of the Region as the calculation of the needs of employees, (b). Position Analysis, Central Lampung Health Office in terms of job analysis to analyze the need to prioritize positions that are technically or strategically by taking into account the type of educational qualifications required for the job, (c). Preparation of Formation, Central Lampung Health Office in the preparation of that preparation civil servants formation includes several stages: (1). The proposed formation of each SKPD taken into account to determine the priority needs of employees and organized into formation Regional Civil Servants, (2). Furthermore, the proposal submission formation Regional Civil Servants submitted to the Ministry of Administrative Reform and Bureaucratic Reform and the Civil Service Agency through the Governor as representative of the government, and (3). Approval of the proposal set additional allocation prisnsip candidate for Civil Servants of Administrative Reform minister. In developing this formation, badan kepegawaian daerah /regional staffing agency (BKD) only as a coordinator in the area, because the authorities are preparing formation on the central governmentto the delegation of authority to the Minister of Administrative Reform in accordance with the principle of unfield system, (d). Procurement Officer, after Civil Servants planning implementation activities carried out, then the next step is to carry out the procurement of civil servants. Civil Servants Procurement is the process of the activities undertaken by an organization to get civil servants who have the ability to carry out the job description that is predetermined. In developing this formation, BKD only as a coordinator in the area, because the authorities are preparing formation on the central government to the delegation of authority to the Minister of Administrative Reform in accordance with the principle of unfield system, (d). Procurement Officer, after Civil Servants planning implementation activities carried out, then the next step is to carry out the procurement of civil servants. Civil Servants Procurement is the process of the activities undertaken by an organization to get civil servants who have the ability to carry out the job description thatis predetermined. In developing this formation, BKD only as a coordinator in the area, because the authorities are preparing formation on the central government to the delegation of authority to the Minister of Administrative Reform in accordance with the principle of unfield system, (d). Procurement Officer, after Civil Servants planning implementation activities carried out, then the next step is to carry out the procurement of civil servants. Civil servant procurement is the process of the activities undertaken by an organization to get civil servants who have the ability to carry out the job description that is predetermined [29].

All stages have been implemented in a coordinated manner, although the Health Department sometimes have dissatisfaction due to a few formations that later changed when the announcement of the selection civil servants in the media. However, changes in the quantity that can be understood as a form of adjustments to the quota given to the Central Lampung Government. In the future it is necessary improve coordination between the agencies proposing the formation by BKD and other involved institutions, it aims to create equity type of health personnel or the quantity of health personnel in each region of Central Lampung.

\subsubsection{Geography, social, economic and security in some areas that encourage movement of health personnel to safer locations/crowded}

One important thing which is an obstacle in remote areas is access. Without access to medical personnel would have difficulty getting information. The need for access is absolutely necessary. Access can be either physical access such as transportation, adequate roads that are useful as a means to help when will refer the patient to a higher level of service. Another access is no less important is the need for better access to the latest information about the development of science as well as on the development of global information. The lack of access that is sometimes discourage medical personnel to enter work in the area [30].

In fact, areas that have the hustle and more complete supporting facilities is still the target of the doctors and other medical personnel to serve. As a result, more than half of doctors and other health workers to accumulate in dense areas. The impact of the distribution of health personnel are unequal impact on society difficulty accessing health services [31].The social factor was a consideration when deciding to become ASN in Central Lampung, conduciveness area is the main factor that leads into the personal. Data from Lampung Police showed that based on administrative areas, from 14 cities in Lampung all have critical points of conflict. This shows that all cities in Lampung Province actually very prone to social conflict. When seen further at the level of city turned out to Central Lampung regency has medium vulnerability with a score of $11.1 \%$. Central Lampung regency position that still includes vulnerability is in need of social conflict at the macro intervention by the Central Lampung regency government.

While in terms of criminality, Central Lampung is an area with theft by weighting which dominates crime cases during 2018. In the course of the operation Brush Krakatau, Lamteng Police crime dealt with 19 cases dominated nozzle. Afterwards theft with violence 14 cases, 11 cases of thief and firearms posession are 2 cases. Increasing cases of nozzle for their pattern of criminality, from night to daytime. While the data Lampung Police said four blackspots in Central Lampung and the other vulnerable point in South Lampung. The security condition is also a great work of stakeholders in Central Lampung, so they can encourage their motivation and interest for the health workers distributed throughout the region in Central Lampung. 


\section{CONCLUSION}

Distribution of existing health workers in primary health care in Central Lampung analyzed into two aspects; (a). Health Power Distribution Analysis by Region. Based on the analysis show that there are health workers who have large quantities, such as Sub Terbanggi Besar, Trimurjo and Padang Ratu. While there are some districts that do not have some type of health personnel, such as Putra Rumbia who do not have medical personnel, (b). Analysis of Power Distribution Based on Workplace Health. There are at least three categories of health personnel placement locations, ie, at the Department of Health, health centers and hospitals. Based on the analysis can be observed if the majority of health workers currently on placement locations clinic.

Factors that affect the process of procurement and distribution of health personnel in primary health care in Lampung, namely; (a). Analysis of the health workers job position have not been done at the health center level. In Central Lampung, job analysis of new health workers carried out at official level, has not been done by each health center. Not to do this job analysis as one of the causes of the unavailability of health workers at the health center level, as well as the causes of the problems that tend to be uneven distribution in the region of Central Lampung, (b). Health Personnel Information System has not been implemented, so that the data has not been collected health workers and exploited better. Maximum use of information systems have not been operated, it is not only caused by because there is insufficient competent operator expertise, geographic regions that have different internet signal strength and also the condition of the electrical infrastructure is not optimal, (c). Coordination between the relevant institutions for recruitment is not optimal, often proposals from the department then changed during the process of formation at the level of BKD or Center. In this case BKD as local institutions responsible as coordinator of the area in the activities of the personnel in the area where one of the activities is the recruitment process Servants Although the Health Department sometimes have dissatisfaction due to a few formations that later changed when the announcement of the selection job formation in media, (d). Geography, social, economic and security in some areas that encourage movement of health personnel to safer locations/crowded. Access can be either physical access such as transportation, adequate roads that are useful as a means to help when will refer the patient to a higher level of service.

\section{ACKNOWLEDGEMENTS}

Thank you to all those who have helped this research, especially the Central Lampung regency government who is very open in facilitating researchers.

\section{REFERENCES}

[1] Hodge, A., Firth, S., Jimenez-Soto, E., \& Trisnantoro, L., "Linkages between decentralisation and inequalities in neonatal health: Evidence from Indonesia," The Journal of Development Studies, vol. 51, no. 12, pp. 1634-1652, 2015.

[2] World Health Organization, "State of health inequality: Indonesia," New York: World Health Organization, 2017.

[3] Misnaniarti M., Hidayat B., Pujiyanto P., Nadjib M., Thabrany H., Junadi P., et al., "Availability of Facilities and Health Workers in Support of National Health Insurance Coverage (In Bahasa: Ketersediaan Fasilitas dan Tenaga Kesehatan Dalam Mendukung Cakupan Semesta Jaminan Kesehatan Nasional)," Jurnal Penelitian Dan Pengembangan Pelayanan Kesehatan, vol. 1, no. 1, pp. 6-16, 2017.

[4] Tadjoeddin, M. Z., "Aspiration to inequality: regional disparity and centre-regional conflicts in Indonesia," WIDER Conference on Spatial Inequality in Asia, pp. 1-34, 2003.

[5] Suryanto S., Boyle M., Plummer V., "Healthcare Workforce in Indonesia," Asia Pacific Journal of Health Management, vol. 12, no. 3, pp. 32-40, 2017.

[6] Pardosi J. F., Parr N., Muhidin S., "Inequity Issues and Mothers' Pregnancy, Delivery and Early-Age Survival Experiences in Ende District, Indonesia," Journal of Biosocial Science, vol. 47, no. 6, pp. 780-802, 2015.

[7] Miharti S., Holzhacker R. L., Wittek R., "Decentralization and Primary Health Care Innovations in Indonesia," Decentralization and Governance in Indonesia, vol. 2, pp. 53-78, 2015.

[8] Jusot F., Mage-Bertomeu S., Menéndez M., "Inequality of Opportunity in Health in Indonesia," 2017. [Online]. Available: https://hal.archives-ouvertes.fr/hal-01507738.

[9] Hosseinporr, A., Nambiar, D., \& Schlotheuber, A., "Monitoring health inequality in Indonesia," Global Health Action, vol. 11, pp. 3-6, 2018.

[10] Efendi F., Kurniati A., "Health Human Resources Study in Indonesia (In Bahasa: Kajian Sumber Daya Manusia Kesehatan Di Indonesia)," Salemba Medika, p. 166, 2012.

[11] Mahendradata, L. T., S. L., P. S., T. M., P. H., et al., "The Republic of Indonesia Health System Review," Health Systems in Transition, vol. 7, no. 1, 2017.

[12] Gomez, E., "Health spending and inequality in the emerging economies," London: Europe Union-Oxfam, 2015.

[13] Koller, T., Saint, V., Floranita, R., \& Koemara Sakti, G., "Applying the Innov8 approach for reviewing national health programmes to leave no one behind: lessons learnt from Indonesia," Global Health Action, vol. 11, pp. 63-69, 2018.

[14] "BPS Lampung Tengah. Lampung Tengah Dalam Angka Tahun 2016 (In Bahasa: Central Lampung BPS. Central Lampung in Figures for 2016," 2017. [Online]. Available: https://lampungtengahkab.bps.go.id/statictable/2016/10/20/500/jumlahpenduduk-menurut-kecamatan-dan-jenis-kelamin-di-kabupaten-lampung-tengah-2014.html. 
[15] Dinkes Lamteng, "Profil Kesehatan Lampung Tengah Tahun 2018 (In Bahasa: Health Profile of Central Lampung in 2018)," Dinas Kesehatan Lampung Tengah, 2018.

[16] Utomo, B., Sucahya, P., \& Utami, F., "Priorities and realities: addressing the rich-poor gaps in health status and service access in Indonesia," International Journal for Equity in Health, vol. 10, no. 47, pp. 1-14, 2011.

[17] Conard M., Schweizer K., "Personality-oriented job analysis to identify non-cognitive factors predictive of performance in a doctor of physical therapy program in the United States," Journal of Educational Evaluation for Health Professions, vol. 15, no. 34, pp. 15-34, 2018.

[18] Gunawan, J. A. Yupin, "Managerial competence of first-line nurse managers: A concept analysis," International Journal of Nursing Practice, vol. 23, no. 1, pp. 233-244, 2017.

[19] Wirawan A., "Analysis of Employee Performance Measurement Factors Using the Human Resources Scorecard Approach (In Bahasa: Analisis Faktor-Faktor Pengukuran Kinerja Pegawai Dengan Menggunakan Pendekatan Human Resources Scorecard)," Jurnal Riset Bisnis dan Manajemen, vol. 5, no. 4, pp. 567-588, 2017.

[20] Dipboye R. L., Dipboye R. L., "Work Analysis," 2018. [Online]. Available: https://www.emerald.com/insight/content/doi/10.1108/978-1-78743-785-220181013/full/html.

[21] Lestari T. R. P., "Analysis of Availability of Health Workers in Mamuju City Health Center, West Sulawesi Province 2014 (In Bahasa: Analisis Ketersediaan Tenaga Kesehatan di Puskesmas Kota Mamuju Provinsi Sulawesi Barat Tahun 2014)," Kajian, vol. 21, no. 1, pp. 75-88, 2017.

[22] Zahtamal Z., Restuastuti T., Chandra F., "Determinant Factor Analysis of Problems in Maternal and Child Health Services (In Bahsa: Analisis Faktor Determinan Permasalahan Pelayanan Kesehatan Ibu dan Anak)," Kesmas National Public Health Journal, vol. 6, no. 1, pp. 9-16. 2011.

[23] Yulianda, "Several Factors Related to Motivation of Health Workers in the Banda Aceh Regional Public Service Agency (In Bahasa: Beberapa Faktor yang Berhubungan dengan Motivasi Tenaga Kesehatan di Badan Layanan Umum Daerah Rumah Sakit Ibu dan Anak Banda Aceh," 2016. [Online]. Available: http://repositori.usu.ac.id/handle/123456789/710.

[24] Hidajat, M. M., "Indonesia's social capacity for population health: The educational gap in active life expectancy," Population Research and Policy Review, vol. 26, no. 2, pp. 219-234, 2007.

[25] Suryana, N. A., et al., "Assessment of Health Human Resources Policy for Health Workers at Community Health Centers in Eastern Indonesia," International Journal of Advances in Scientific Research and Engineering, vol. 5, no. 4, pp. 94-101, 2019.

[26] KemenKes R., "Profile of Indonesian health data for 2011 (In Bahasa: Profil data kesehatan Indonesia Tahun 2011," Jakarta Kementerian Kesehatan Republik Indonesia, 2012.

[27] Malkin, R., et al., "Medical Imaging in Global Public Health: Donation, Procurement, Installation, and Maintenance," Radiology in Global Health, vol. 10, no, 1, pp. 77-83, 2019.

[28] Ahsan, K., "Green public procurement implementation challenges in Australian public healthcare sector," Journal of Cleaner Production, vol. 152, no. 5, pp. 181-197, 2017.

[29] Ansuategui Echeita, J. V., "Association between social factors and performance during Functional Capacity Evaluations: a systematic review," Disability and rehabilitation, vol. 41, no. 16, pp. 1863-1873, 2019.

[30] Goemaes, R. B., “Advanced midwifery practice: An evolutionary concept analysis," Midwifery, vol. 41, no. 7, pp. 29-37, 2016.

[31] Wolicki, S. B., "Public health surveillance: at the core of the Global Health Security Agenda," Health security, vol. 14, no. 3, pp. 185-188, 2016. 